УДК 504.052

Технологический менеджмент рационального природопользования (по материалам угольных месторождений Монголии)

\author{
Чимэддорж Удвалноров ch.udvalnorov@gmail.com \\ Санкт-Петербургский горный университет \\ 199106, Санкт-Петербург, Васильевский остров, 21 линия, 2
}

Актуальность представленного исследования состоит в том, что экономика Монголии относится к числу тех, которые развиваются в современном рынке за счет использования минерально-сырьевых ресурсов, но не отказываются от целей модернизации. Подобный опыт важен для сопоставления возможностей и перспектив российской экономики, которая также является сырьевой. Статья нацелена на изучение особенностей добычи и использования угля в Монголии с учетом размещения угольных месторождений, объемов запасов угля и их качественных характеристик, а также уровня развития в стране транспортнологистической инфраструктуры. Представлены основные этапы и современных тенденций развития угольного рынка в азиатско-тихоокеанском регионе, а такжее перспективы торговли с Китаем. Основныл подходом к исследованию является экономико-статистический анализ основных характеристик и показателей развития угольного рынка, функциональный анализ и экспертные оценки, применяемые для изучения внутреннего спроса, закономерностей и перспектив развития экспорта, динамики добычи угля и особенности его использования на внутреннем рынке. В качестве результата исследования предложена методика ранжирования участков угольных месторождений по признаку величины приращённой ценности применительно для экспортируемого угля. Данная методика позволяет более обосновано предлагать комплекс мер по технологическому менеджменту рационального природопользования и со стороны государства, и конкретных компаний - производителей угля. Выводы могут быть полезны в области технологического менеджмента угольной отрасли в сырьевых экономиках. Общицми составляющцими такого менеджсмента является политику цен, зависящую от развития потребностей экономики основного потребителя, внедрение инноваций для роста производительности труда и решение транспортно-логистических проблем, которые при своей запущенности снижают эффективность угольной отрасли, а значит - сдерживают рост экономики в целом.

Ключевые слова: уголь, использования угля, угольных месторождений, ценности угольных месторождений, качественные характеристики угля, угольная отрасль.

DOI: $10.17586 / 2310-1172-2018-11-2-110-121$

\title{
Technological management of rational nature management (based on the datas from coal deposits in Mongolia)
}

\author{
Chimeddorj Udvalnorov ch.udvalnorov@gmail.com \\ St. Petersburg Mining University \\ 2, 21 st Line, St Petersburg 199106, Russia
}

The relevance of the presented study is that the economy of Mongolia is one of those that are developing in the modern market through the use of mineral resources, but do not abandon the goals of modernization. Such experience is important for comparing the opportunities and prospects of the Russian economy, which is also a raw material one. The article aims to study the features of coal production and use in Mongolia, taking into account the location of coal deposits, the volume of coal reserves and their quality characteristics, as well as the level of development of transport and logistics infrastructure in the country. The main stages and current trends of the coal market in the Asia-Pacific region, as well as the prospects of trade with China are presented. The main approach to the research is the economicstatistical analysis of the foundations regarding characteristics and indicators of development of the coal market, a functional analysis according to expert estimates, applied for the investigation of internal demand, trends and prospects-tiv export development, dynamics of coal mining and especially its use on internal it market. The conclusions can be useful in the field of technological management of the coal industry in the raw materials economies. The common components of such management are price policy, which depends on the development of the needs of the main consumer economy, the introduction of innovations for the growth of labor productivity and the solution of transport and logistics problems, which, when neglected, reduce the efficiency of the coal industry, and thus constrain the growth of the economy as a whole.

Keywords: coal, use of coal, coal deposits, values of coal deposits, quality characteristics of coal, coal industry. 


\section{Введение}

С 1990-х гг начались экономические реформы в Монголии. Экономическая система страны полностью перешла от централизованно-плановой системы на рыночную. По мере развития научно-технического прогресса, роста численности населения, объемов производства возросло влияние горнодобывающей отрасли на экономический рост и экономическую устойчивость страны.

В настоящее время Монголия - страна, экономика которой активно развивается. Одним из конкурентоспособных минеральных ресурсов Монголии является уголь, объемы запасов которого, а также спрос на данный вид ресурса велики и определяет характер экономики страны как сырьевой. Уголь в стране занимает первое место по объему запасов [1], тогда как запасы таких других ресурсов как нефть и газ [2] отсутствуют. При бурном развитии экономики Монголии добыча угля выступает системообразующим фактором экономического роста и социального развития страны [3]. В контексте общих подходов развития территорий и отраслей [4], а также хозяйственных практик многих стран мира, следует отметить, что использование угля как ресурса в тех или иных целях востребовано на долгие годы [5]. В этих условиях повышается актуальность развития теоретических положений и методических подходов в экономической оценке угольных месторождений с учётом влияния факторов, действующих на угольных рынках азиатско-тихоокеанского региона (АТР).

Поэтому, несмотря на то, что добыча и использование угля имеют ряд неоднозначных последствий для модернизации экономики, Монголия не отказывается от эксплуатации месторождений угля, выгодной реализации его на мировом рынке (через постоянных торговых партнеров при соответствующе политики цен), а также эффективного использования, полученных доходов для социально-экономического развития экономики страны в целом. Анализу технологий, управленческого комплекса методов, обеспечивающих рациональную эксплуатацию месторождений угля, его реализацию и использование полученных доходов, применяемых в современной Монголии, посвящается данная статья. Опыт технологического менеджмента экономики сырьевой страны в определенной мере значим для других стран, имеющих сырьевую направленность, в том числе и для России. Несмотря на существующий исследовательский интерес к методам экономической оценки угольных месторождений и эффективному использованию угольных месторождений [6], учет особенностей развития угольного рынка Монголии носит проблемный характер.

Представленное исследование основывается на экономико-статистическом, функциональном анализе, экспертных оценках, включающих составление рейтингов, оценочных коэффициентов и др., что позволяет показать и стратегически оценить состояния дел современной Монголии.

\section{Основная часть}

Краткий анализ состояния дел показывает, что добыча угля в Монголии в рамках прошедших десятилетий развивается, однако объемы добычи постоянно варьируются под влиянием ряда внутренних и, главным образом, внешних факторов (рис 1).

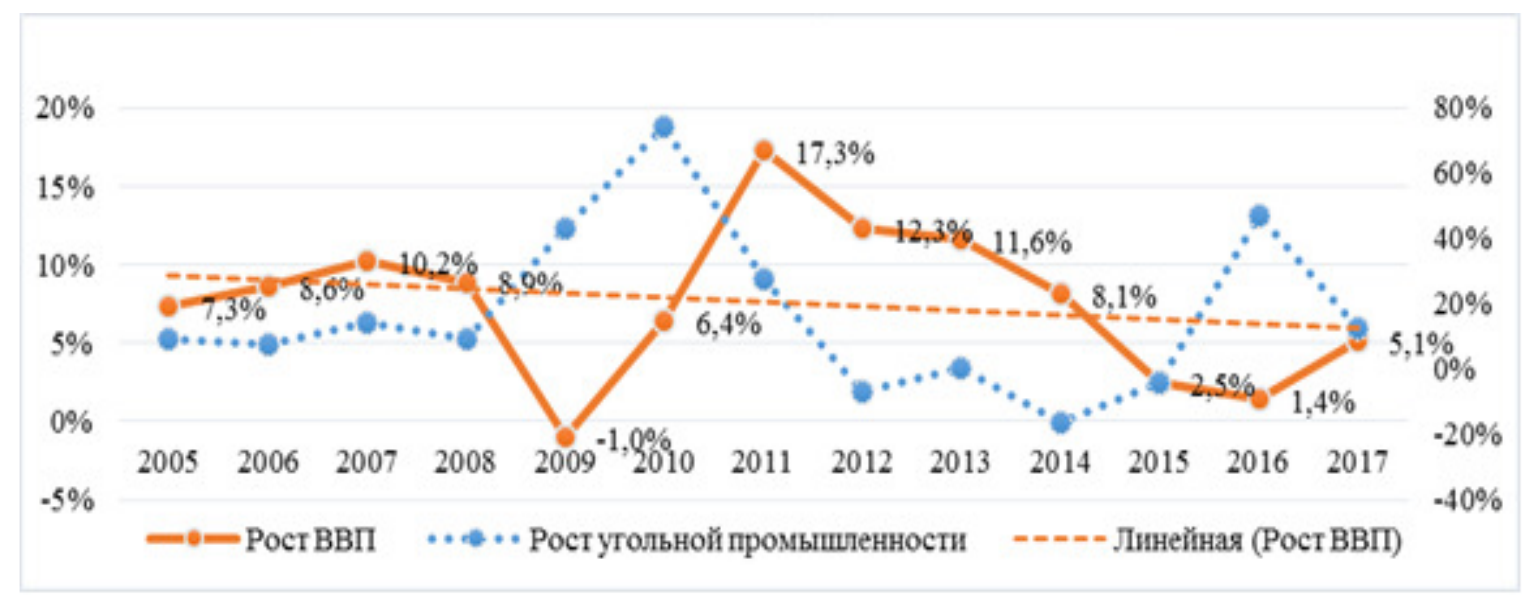

Рис. 1. Экономический рост и добыча угля Монголии [7], [8]

До настоящего времени в Монголии уголь используется, главным образом, как топливно-энергетическое сырье. В качестве топливно-энергетического сырья он потребляется многими отраслями экономики (рис. 2).

В соответствии с мировой практикой использования технологических инноваций в переработке угля благодаря использованию данного продукта получают более 400 различных товаров. Но в Монголии уголь не перерабатывается в высокоценную продукцию и недостаточно реализуется на международном рынке. 
С другой стороны, под влиянием современных научно-технических достижений и их применения в угольной отрасли существенно меняются способы добычи и производственного потребления угля. В результате внедрения достижений изменяются количественные и качественные показатели использования угля как ресурса [5].

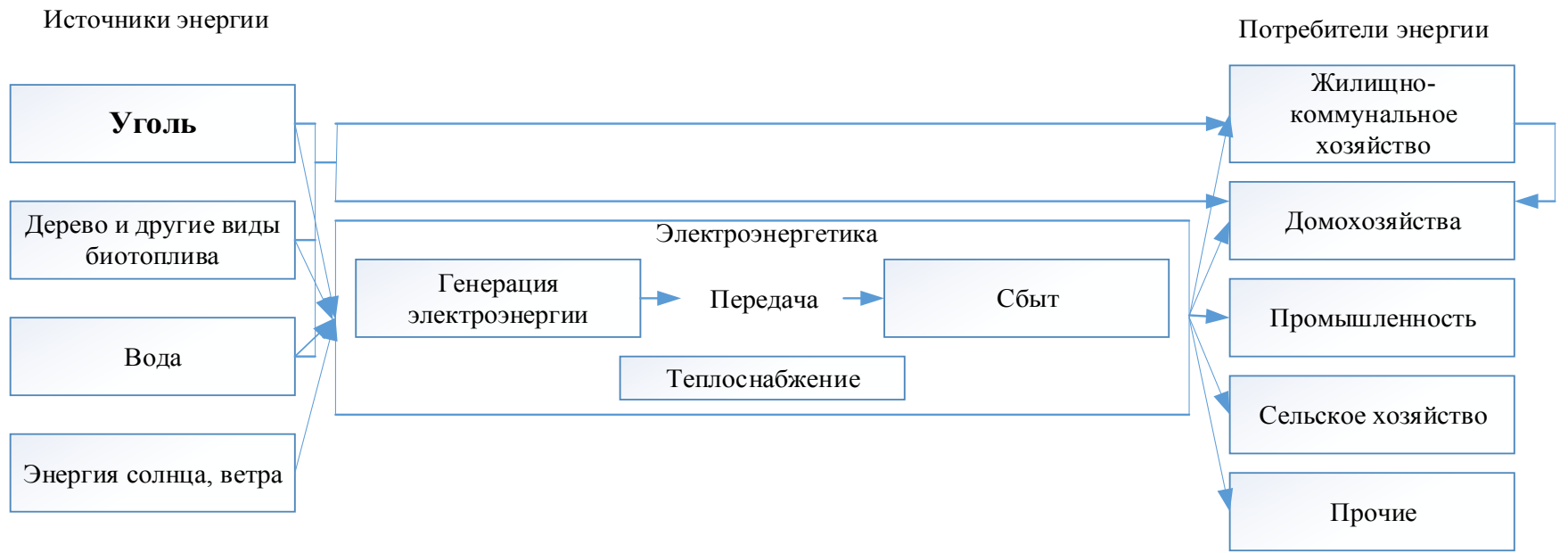

Рис. 2. Направления использования угля как источника энергии

В Монголии слабо развивается транспортно-логистическая инфраструктура многих территорий страны, а это, в свою очередь, препятствует развитию угольного рынка и, в частности роста объёмов экспортных операции угледобывающих предприятий [9].

С учётом факторов, действующих на угольных рынках АТР, на экономическую оценку угольных месторождений влияет следующее. Так, ценность угольных месторождений Монголии формируется под влиянием внутренных и внешних факторов. К внутренным факторам относятся качественные характеристики угля, горно-геологические и горно-технические условия месторождения. К внешним факторам относятся возможности внедрения инноваций при использовании угля, перспективы обогащения угля, развитие угольных рынков АТР и создание транспортно-логистической инфраструктуры в стране.

В результате анализа экономических показателей добычи и использования угля в Монголии были получены данные, свидетельствующие о том, что в настоящее время в угольной отрасли страны протекает ряд объективных закономерностей и устойчивых тенденций, которые состоят в следующем.

1. Существующие в настоящее время собственные потребности угля на внутреннем рынке страны не способны «покрыть» ресурсные возможности угледобывающих компаний, производственные мощности которых в долгосрочном временном интервале растут [5].

2. Относительно низкие объемы потребления угля на внутреннем рынке Монголии объясняются практически отсутствием на территории страны перерабатывающих производств, которые бурно развиваются в других странах АТР, все, увеличивая объемы использования угля в производственных целях.

3. В силу географических особенностей Монголии и располагаемого мощного ресурнопроизводственного потенциала в угольной отрасли в долгосрочной перспективе добываемый в стране уголь должен активно поступать на угольный рынок АТР. Близость Китая является благоприятным фактором, способствующим росту объемов экспорта угля в эту страну [3].

4. Выгодность экспортируемого угля в Китай для Монголии очевидна. Экспортируется каменный уголь в Китай с самыми высокими значениями показателей характеристики теплоты сгорания [2]. Этот экспортируемый уголь самый дорогой и поэтому он больше всего создает благоприятные условия для повышения эффективности производственно-коммерческой деятельности угледобывающих компаний Монголии. Это подтверждают и данные экономической отчетности соответствующих компаний.

5. В связи с крайне неразвитой транспортно-логистической инфраструктурой в Монголии стоимость угля резко возрастает на величину его транспортировки. В стране наблюдается острый дефицит в автомобильных дорогах и, что особенно важно, в железной дороге [10].

6. Автомобильные грузовые тарифы существенно превышают железнодорожные [11], [12]. Это повышает актуальность разработки и реализации проектов строительства и ввода в эксплуатацию, во-первых, железных дорог, и, во-вторых, автомобильных, что резко повысит эффективность перевозок угля и будет способствовать росту его ценности. 
Объём добычи угля в Монголии с 1990-х годов до 2004 года оставался стабильным и удовлетворял только национальное потребление. С 2004 года уголь стал экспортироваться в другие страны, в связи с чем добыча угля резко возросла (рис. 3).

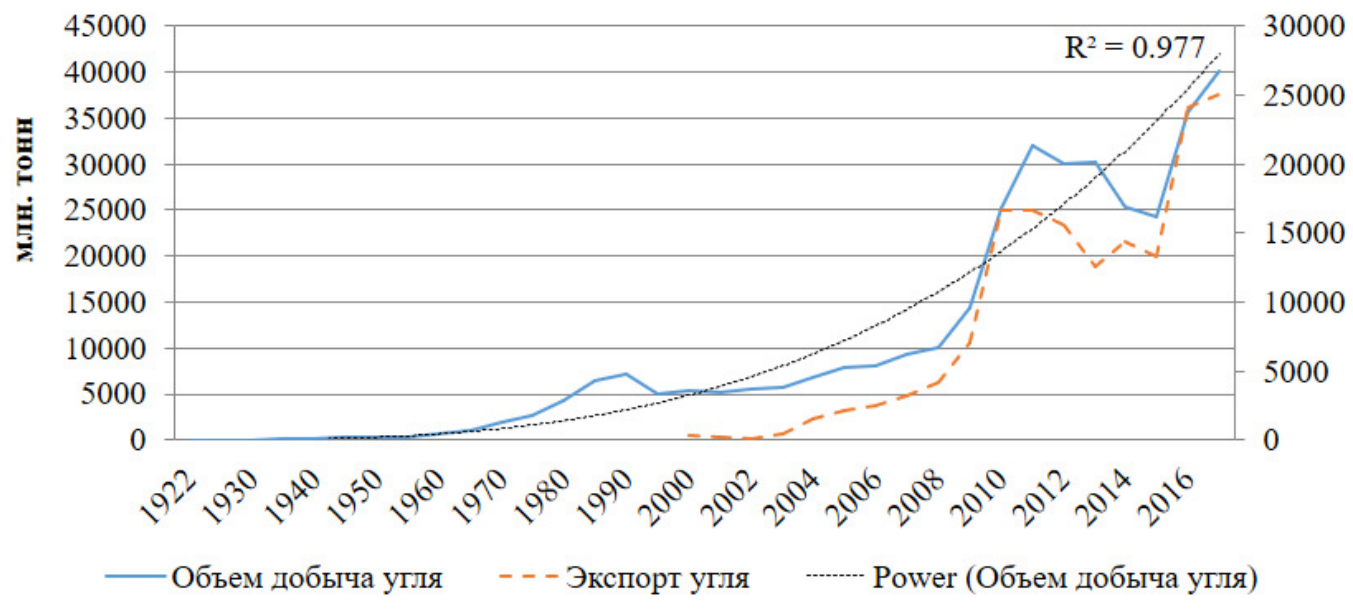

Рис. 3. Динамика изменения общих объемов добычи угля и его экспорт в Монголии (1922-2017 г2.) [10]

Имеющиеся месторождения больших объёмов запасов угля с высокими значениями показателя теплоты сгорания, приближенного к стандартам Китая, а также тенденции развития угольного рынка АТР являются определяющими факторами в выходе угледобывающих компаний на внешний рынок и росте ценности угольных месторождений.

В настоящее время в КНР проводится политика модернизации угольной отрасли, что способствует реализации инноваций в угольной промышленности: разработка современных способов добычи, проектирования нового добывающего оборудования, внедрения современных методов дегазации и т. п., повышения безопасности производства, расширения связей с другими странами, международного сотрудничества.

Устойчивый рост и торговые партнеры являются комплементарными составляющими для развития угольной отрасли экономики Монголии и эффективного использования ее конкурентных преимуществ. Условия, способствующие устойчивому росту потребности в угле Монголии, связанны с Китаем как с главным зарубежным покупателем.

Китайская народная Республика (КНР) является космической и ядерной державой со смешанной схемой управления экономикой: координация экономической деятельности страны осуществляется Коммуной

Основной отраслью КНР в настоящее время является промышленность (от 40 до 50\% ВВП). Основными секторами промышленности КНР являются: горная промышленность и переработка руды, производство железа и стали, алюминия, машиностроение, производство вооружения, химическая промышленность, производство удобрений, пищевая промышленность, производство транспортного оборудования (в т.ч. производство автомобилей, вагонов и локомотивов, морских и речных судов, самолетов), прочие.

КНР является одним из мировых лидеров по производству энергоносителей, при этом три четверти общего объема выработки электроэнергии обеспечивается за счет угля, 20\% - за счет нефти, а газ и иные виды топлива оказывают незначительный вклад в выработку электроэнергии. Объемы добычи угля основных мировых производителей представлены в табл.

Динамика добычи угля по основным странам, в которых осуществляется добыча угля, представлена в табл. 1. Как показывают данные табл. 1, наиболее значительные темпы роста добычи угля наблюдаются в таких странах как Индонезия, Китай, Индия, Австралия. Темпы роста добычи угля в Китае за последние 30 лет уступают лишь Индонезии, однако также являются весьма значительными. Однако среднегодовые темпы роста добычи угля в Китае с 2010 г. составляют 2,63 \%. Наиболее высокие темпы роста наблюдались с 2000 по 2010 гг.

При этом необходимо отметить достаточно высокий уровень концентрации добычи угля в мире. В качестве сравнения отметим, что в Российской Федерации доля десяти крупнейших угольных компаний в общей добыче по стране составляет 75\% [13].

Мировое потребление угля в настоящее время имеет тенденцию к снижению, но азиатский регион в целом находится на первом месте в мире по потреблению угля (табл. 2) 
Добыча угля по странам мира, млн. т.

\begin{tabular}{|l|c|c|c|c|c|c|c|c|}
\hline \multirow{2}{*}{ Год } & \multicolumn{7}{|c|}{ Страна } \\
\cline { 2 - 9 } & Китай & США & Индонезия & Австралия & Индия & РФ & $\begin{array}{c}\text { Мир } \\
\text { в целом }\end{array}$ & $\begin{array}{c}\text { Доля } \\
\text { 10 стран, \% }\end{array}$ \\
\hline 1985 & 436,1 & 487,0 & 1,2 & 88,3 & 71,4 & 179,3 & 2104,4 & 73,9 \\
\hline 1990 & 539,9 & 565,9 & 6,6 & 109,3 & 91,9 & 178,3 & 2264,5 & 78,1 \\
\hline 1995 & 680,4 & 555,1 & 25,7 & 130,1 & 117,7 & 120,0 & 2252,4 & 84,2 \\
\hline 2000 & 707,1 & 570,1 & 47,4 & 166,9 & 132,2 & 116,9 & 2310,1 & 86,7 \\
\hline 2005 & 1327,8 & 590,3 & 119,2 & 211,6 & 170,2 & 145,5 & 3174,7 & 90,3 \\
\hline 2010 & 1664,9 & 551,2 & 169,2 & 240,5 & 217,5 & 151,4 & 3604,3 & 91,5 \\
\hline 2011 & 1852,6 & 556,1 & 217,3 & 233,4 & 215,7 & 158,8 & 3869,4 & 91,6 \\
\hline 2012 & 1872,5 & 517,8 & 237,3 & 250,4 & 229,1 & 169,5 & 3912,9 & 92,0 \\
\hline 2013 & 1893,7 & 500,9 & 276,2 & 268,2 & 228,8 & 168,8 & 3961,4 & 92,2 \\
\hline 2014 & 1844,6 & 507,8 & 281,7 & 280,8 & 243,5 & 170,9 & 3933,5 & 92,7 \\
\hline $\begin{array}{l}\text { Рост } \\
\text { к } 1985 \text { г., \% }\end{array}$ & 322,9 & 4,3 & 22800 & 218,1 & 240,9 & $-4,7$ & 86,9 & - \\
\hline
\end{tabular}

Таблица 2

Потребление угля в мире в 2016 г. [14]

\begin{tabular}{|l|c|c|}
\hline \multicolumn{1}{|c|}{ Регион } & $\begin{array}{c}\text { Доля } \\
\text { в потреблении } \\
\text { угля, \% }\end{array}$ & $\begin{array}{c}\text { Увеличение (уменьшение) } \\
\text { потребления угля } \\
\text { с 2000 по 2016 г., \% }\end{array}$ \\
\hline Страны Азии & 69,0 & $+148,5$ \\
\hline Страны Европы & 11,3 & $-14,2$ \\
\hline Северная Америка & 9,4 & $-33,1$ \\
\hline Страны бывшего СССР & 4,7 & $-1,4$ \\
\hline Африка & 2,8 & $+24,1$ \\
\hline Австралия и Новая Зеландия & 1,8 & $-9,1$ \\
\hline Латинская Америка & 0,9 & $+48,9$ \\
\hline
\end{tabular}

В рамках настоящего исследования необходимо особо отметить фактор, который может оказать влияние на возможности поставок в КНР угля из Монголии. Данным фактором являются особенности развития инфраструктуры в Китае: в связи с транспортными проблемами цена угля в отдаленных провинциях выше, чем в областях, в которых он добывается. Данный фактор может быть использован при планировании поставок добытого в Монголии угля в провинции Китая, близкие к границе с Монголией. Все это позволяет сделать вывод о возможности использования КНР как целевого рынка для внешних производителей угля.

Однако при этом необходимо учитывать такое ограничение как импортные пошлины, установленные решением Министерства финансов КНР в 2014 г. Ранее пошлинами облагался лишь бурый уголь. Размеры указанных пошлин составляют: на антрациты и коксующиеся угли $-3 \%$, на каменные угли $-6 \%$, на остальные угли $-5 \%[14]$.

Методика по определению ценности участков угольных месторождений Монголии при их выборе с учетом экспортных возможностей угля, должен учитывать совокупность характеристик качества угля, соответствующих стандарту КНР, состояние и перспективы развития транспортно-логистической инфраструктуры и ценовую конкурентоспособность угля.

На территории Монголи и разведано более 40 месторождений угля, в том числе каменного угля, бурого угля, а также антрацита. Из всех разведанных месторождений в настоящее время активных 20 месторождений. Добыча осуществеляется угледобывающими компанями, наиболее крупные из них Тавантолгой, Нарийнсухайт, Багануур, Шивээ-Овоо и т.е.

Что касается потребления угля: если Монголия в 2000 году занимала $85 \%$ общей потребности теплоэлектростанций, то в 2008 году $-83 \%$, в 2016 году - 78\%, то есть доля общего потребления неуклонно 
снижалась, тогда как общий объем потребления угля в 2000-2016 годах увеличился на 51,2\% [10].

Поскольку теплота сгорания каменного угля во многих месторождениях Монголии максимально приближена к стандартам Китая, то экспорт этого угля в Китай имет большие перспективы, что существенно повышает ценность соответствующих угольных месторождений: цена угля на экспорт намного превышает цену потребляемого угля на внутреннем рынке. Таким образом, есть возможность экспортировать большие объёмы добываемого угля в Китай, у которого потребность в угле устойчивая и высокая.

Для оценки потенциала развития экспорта угля в Китай нами были проанализированы активные угольные месторождения, запасы угля которых имеют высокую теплоту сгорания-более 5500 ккал/кг. В результате были выделены 6 месторождений запасы угля которых соответствовали значению этого показателя. (табл. 3).

Таблица 3

\section{Качественные характеристики угля по месторождениям [15]}

\begin{tabular}{|c|c|c|c|c|c|}
\hline $\begin{array}{c}\text { Название } \\
\text { месторождения }\end{array}$ & $\begin{array}{c}\text { Место- } \\
\text { нахождение }\end{array}$ & $\begin{array}{c}\text { Влажность } \\
\mathrm{W}_{\mathrm{rt}}(\%)\end{array}$ & $\begin{array}{c}\text { Зольность } \\
\mathrm{A}_{\mathrm{d}}(\%)\end{array}$ & $\begin{array}{c}\text { Содержание } \\
\text { серы } \mathrm{S}_{\mathrm{dt}}(\%)\end{array}$ & $\begin{array}{c}\text { Теплота сгорания } \\
\mathrm{Q}_{\mathrm{rl}}(\text { ккал/кг })\end{array}$ \\
\hline Хартарбагатай & Увс & 16 & 20 & 0,5 & 5500 \\
\hline Хөшөөт & Ховд & 7 & 16,5 & 0,5 & 5850 \\
\hline Могойн гол & Хөвсгөл & 6,5 & 18 & 0,9 & 5450 \\
\hline Сайхан-Овоо & Булган & 5,7 & 21,7 & 0,6 & 6100 \\
\hline Тавантолгой & Өмнөговь & 6,9 & 14,9 & 0,5 & 6500 \\
\hline Нарийн сухайт & Өмнөговь & 5 & 17,5 & 0,4 & 7200 \\
\hline
\end{tabular}

Примечание: составлено автором

Исследования трех месторождений - Тавантолгой, Нарийнсухайт, Хөшөөт - территориально близко размещеных к границе Монголии с Китаем, показали, что экспортные поставки добываемого угля в Китай осуществляются успешно. Для выявления неиспользованных возможностей наращивания ценности активных месторождений были проанализированы другие три месторождения Хартарвагатай, Могойн гол, Сайхан-Овоо. Далее оказалось что одно из трёх месторожденией Хартарвагатай имеет низкие запасы угля 33,5 млн.т в объёме.

В связи с этим в качестве объекта анализа были определены 2 месторождения Могойн гол и Сайхан-Овоо с большими объёмами разведанных запасов 330,7 млн.т и 645,5 млн.т с высокой теплота сгорания 5450ккал/кг и 6100ккал/кг. Каждое из анализируемых месторождений угля имеет три лицензионных участка, расположенные территориально поблизости друг от друга, но имеющие разные качественные характеристики угля (табл. 4).

Таблица 4

\section{Качественные характеристики угля по лицензионным участкам}

\begin{tabular}{|c|c|c|c|c|c|}
\hline $\begin{array}{c}\text { Название } \\
\text { месторождения }\end{array}$ & Участок & $\begin{array}{c}\text { Влажность } \\
\mathrm{W}_{\mathrm{rt}}(\%)\end{array}$ & $\begin{array}{c}\text { Зольность } \\
\mathrm{A}_{\mathrm{d}}(\%)\end{array}$ & $\begin{array}{c}\text { Содержание } \\
\text { серы } \mathrm{S}_{\mathrm{dt}}(\%)\end{array}$ & $\begin{array}{c}\text { Теплота } \\
\text { сгорания } \\
\text { (ккал/кг) }\end{array}$ \\
\hline \multirow{3}{*}{ Могойн гол } & $\mathrm{I}$ & 6,5 & 18 & 0,9 & 5450 \\
\cline { 2 - 6 } & $\mathrm{II}$ & $9,2-10$ & 18,8 & 0,73 & 5500 \\
\hline \multirow{3}{*}{ Сайхан-Овоо } & $\mathrm{III}$ & $5,4-9,0$ & $7,4-27,9$ & $0,74-1,33$ & $5393-7055$ \\
\cline { 2 - 6 } & $\mathrm{I}$ & 5,7 & 21,7 & 0,6 & 6100 \\
\cline { 2 - 6 } & $\mathrm{III}$ & $4,81-9,22$ & 20,87 & 0,72 & $6783-7503$ \\
\hline
\end{tabular}

Примечание: составлено автором 
Отметим средние значения качественных показателей по отдельным лицензионным участкам. Применив метод пересчёта цены на основе изменения значений качественных характеристик рассчитаем измение цены угля по лицензионным участикам.

На ценность угольного месторождения оказывают влияние не только качественные характеристики, но и местонаходение участка пограничных территорий с учетом протяжённости, а также состояние существующих автомобильных дорог и железной дороги.

Для обеспечения экспорта угля в Китай необходимо руководствоваться значениями качественных характеристик угля в соответствии со стандартами Китая (табл. 5).

Таблица 5

\section{Качественные характеристики угля в соответствии со стандартами Китая [16]}

\begin{tabular}{|c|c|}
\hline $\begin{array}{c}\text { Показатели } \\
\text { качества угля }\end{array}$ & $\begin{array}{c}\text { Соответствие } \\
\text { стандартам Китая }\end{array}$ \\
\hline Зольность, \% & $<15$ \\
\hline Содержание влаги, \% & $<10$ \\
\hline Содержание серы, \% & $\leq 1$ \\
\hline $\begin{array}{l}\text { Удельная теплота } \\
\text { сгорания, ккал/кг }\end{array}$ & $5500-6000$ \\
\hline
\end{tabular}

Себестоимость экспортируемого угля включает себестоимость его добычи и транспортные расходы.

Каждый лицензионный участок имеет запасы угля, экспортируемая цена которого различна под влиянием качественных характеристик и внешних факторов-протяжённости и состояния дороги (табл. 6).

Таблица 6

\section{Отдаленность месторождений до границы Китая}

\begin{tabular}{|c|c|c|}
\hline \multirow{2}{*}{ Месторождения } & \multicolumn{2}{|c|}{ Тип дороги } \\
\cline { 2 - 3 } & Автомобильная дорога & Железная дорога \\
\cline { 2 - 3 } & До Эрдэнэт & от Эрдэнэт до границы Китай \\
\hline Могойн гол & 608 & 1118 \\
\hline Сайхан-Овоо & 177 & 1118 \\
\hline
\end{tabular}

Примечание: составлено автором

Далее определим расчетную цену угля по лицензионным участкам месторождений (табл. 7), учитывая, что в Монголии тариф на грузоперевозку 1 тн./км. по автомобильной дороге составляет 0.09 \$ США, а железнодорожным транспортом существенно ниже - 0.018 \$ США. 
Таблица 7

Формирование расчётной цены угля по лицензионным участкам месторождений

\begin{tabular}{|c|c|c|c|c|c|c|c|c|c|c|c|}
\hline $\begin{array}{c}\text { Название } \\
\text { месторождения }\end{array}$ & 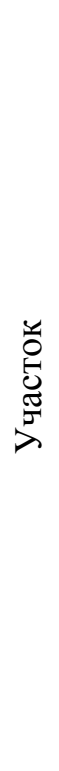 & 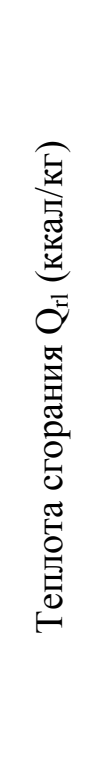 & 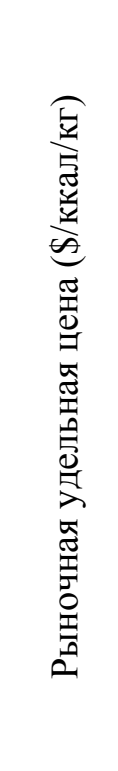 & 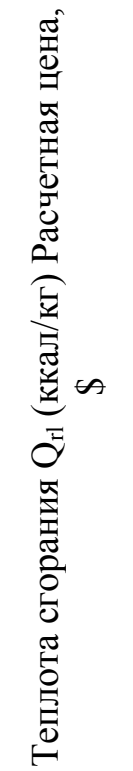 & 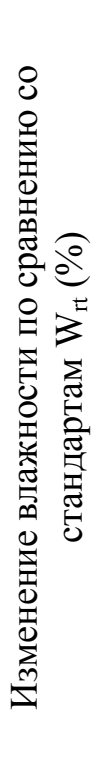 & $\begin{array}{l}0 \\
0 \\
0 \\
0 \\
0 \\
0 \\
0 \\
0 \\
0 \\
0 \\
0 \\
0\end{array}$ & 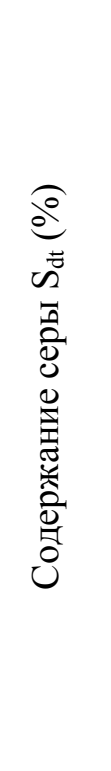 & 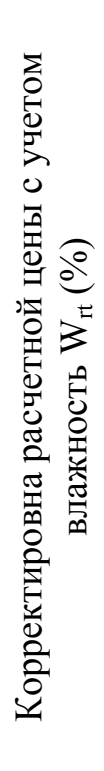 & 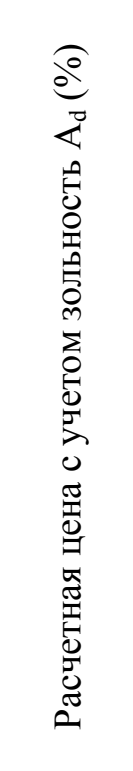 & 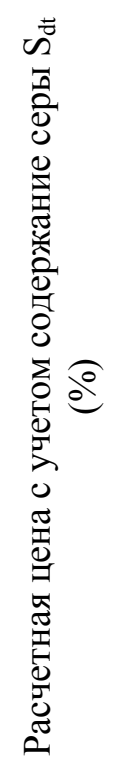 & 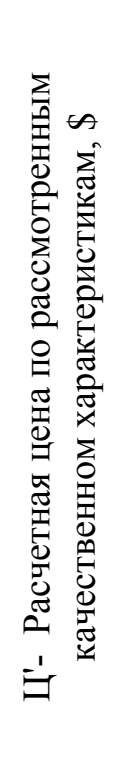 \\
\hline \multirow{3}{*}{ Могойн гол } & I & 5450 & \multirow{6}{*}{0,0178} & 96,96 & 3,5 & -3 & 0,1 & 4,41 & $-7,27$ & 0,04 & 94,15 \\
\hline & II & 5500 & & 97,85 & 0,4 & $-3,8$ & 0,27 & 0,51 & $-9,29$ & 0,13 & 89,20 \\
\hline & III & 6224 & & 110,73 & 2,8 & $-2,65$ & $-0,04$ & 4,03 & $-7,34$ & $-0,02$ & 107,41 \\
\hline \multirow{3}{*}{ Сайхан-Овоо } & $\mathrm{I}$ & 6100 & & 108,53 & 4,3 & $-6,7$ & 0,4 & 6,07 & $-18,18$ & 0,22 & 96,63 \\
\hline & II & 7143 & & 127,08 & 2.98 & $-5,87$ & 0,28 & 4,92 & $-18,65$ & 0,18 & 113,53 \\
\hline & III & 6070 & & 107,99 & 1,95 & -5 & $-0,1$ & 2,74 & $-13,49$ & $-0,05$ & 97,18 \\
\hline
\end{tabular}

Примечание: рассчитано автором 
Оценка прибыли на 1т угля

Таблица 8

\begin{tabular}{|c|c|c|c|c|c|c|c|c|c|c|c|}
\hline \multirow{2}{*}{$\begin{array}{c}\text { Название } \\
\text { месторож- } \\
\text { дения }\end{array}$} & \multirow[t]{2}{*}{ 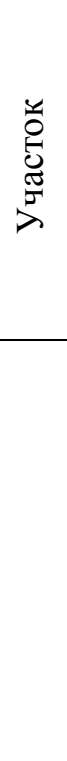 } & \multirow{2}{*}{ 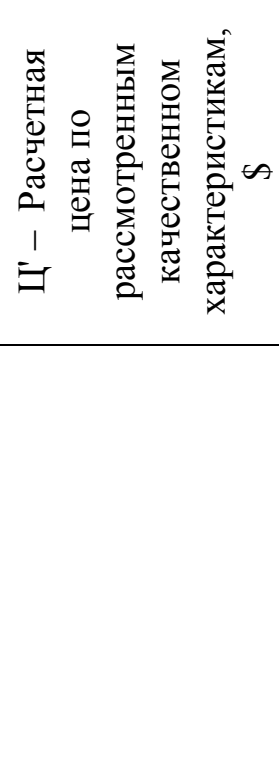 } & \multicolumn{2}{|c|}{$\begin{array}{c}\text { Расстояние до } \\
\text { границы с Китаем }\end{array}$} & \multicolumn{2}{|c|}{$\begin{array}{c}\text { Вид транспорта } \\
\text { до Китая }\end{array}$} & \multirow{2}{*}{ 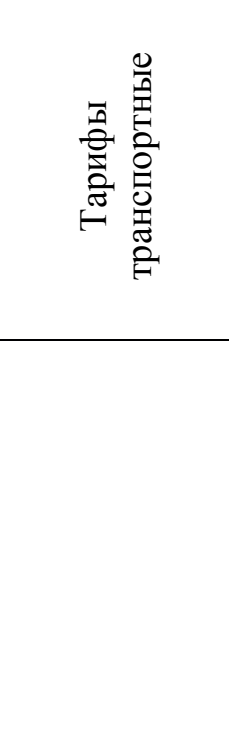 } & \multirow{2}{*}{ 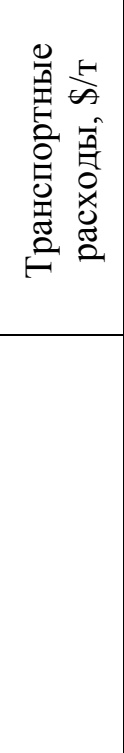 } & \multirow{2}{*}{ 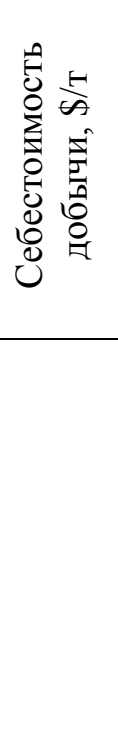 } & \multirow{2}{*}{ 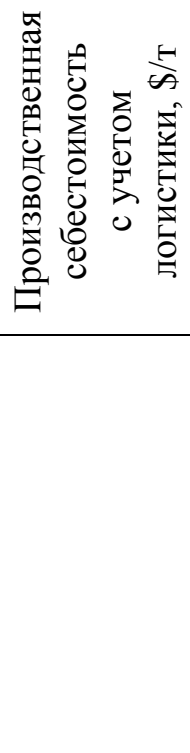 } & \multirow{2}{*}{ 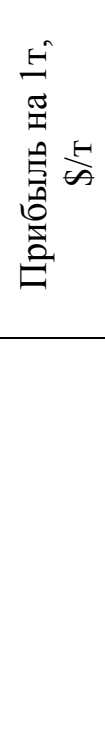 } \\
\hline & & & 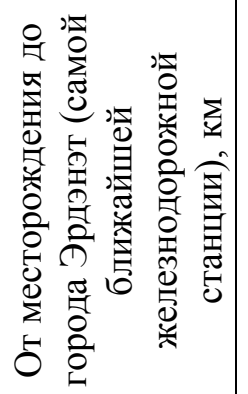 & 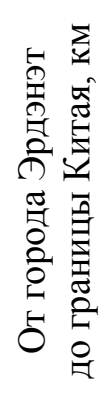 & 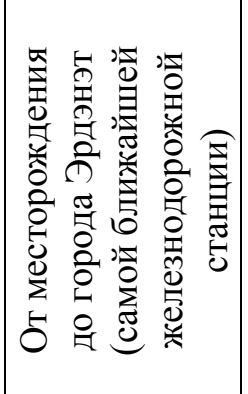 & 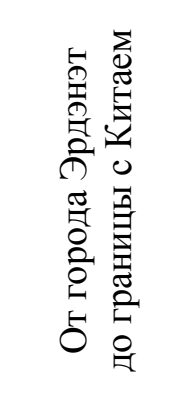 & & & & & \\
\hline \multirow{3}{*}{$\begin{array}{l}\text { Могойн } \\
\text { гол }\end{array}$} & $\mathrm{I}$ & 94,15 & \multirow{3}{*}{609} & \multirow{6}{*}{1118} & \multirow{6}{*}{ Автомобиль } & \multirow{6}{*}{$\begin{array}{l}\text { Железная } \\
\text { дорога }\end{array}$} & \multirow{6}{*}{$\begin{array}{c}\text { Автомобиль } \\
1 \text { тн.км - } \\
0,09 \$ \\
\text { Железная } \\
\text { дорога } \\
1 \mathrm{Tн} / \text { км - } \\
0,018 \$\end{array}$} & 74,84 & 15,1 & 89,94 & 4,21 \\
\hline & II & 89,20 & & & & & & 74,84 & 13,8 & 88,64 & 0,56 \\
\hline & III & 107,41 & & & & & & 74,84 & 15,5 & 90,34 & 17,07 \\
\hline \multirow{3}{*}{$\begin{array}{c}\text { Сайхан- } \\
\text { Овоо }\end{array}$} & $\mathrm{I}$ & 96,63 & \multirow{3}{*}{177} & & & & & 36,23 & 12,6 & 48,83 & 47,80 \\
\hline & II & 113,53 & & & & & & 36,23 & 15,9 & 52,13 & 61,40 \\
\hline & III & 97,18 & & & & & & 36,23 & 14,2 & 50,43 & 46,75 \\
\hline
\end{tabular}

Примечание: рассчитано автором 
Из табл. 8 видно, что приращение ценности угольных месторождений по лицензионным участкам варьирует. Поэтому условия использования экспортируемого угля по разным месторождениям и лицензионным участкам различные.

В результате проведённых исследований сформулируем алгоритм ранжирования участков угольных месторождений по признаку величины приращённой ценности для экспортируемого угля.

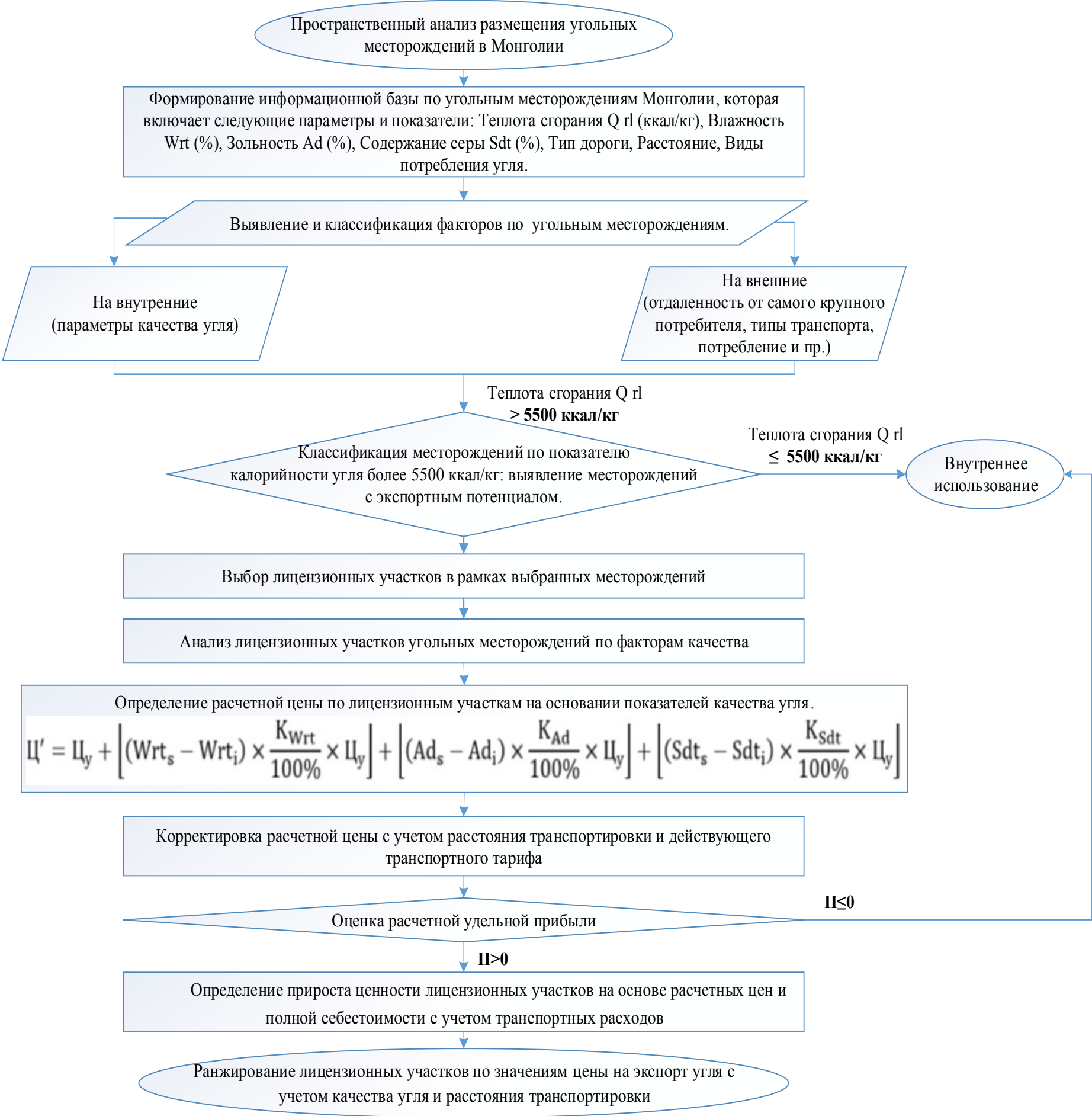

Рис. 4. Алгоритм ранжирования участков угольных месторождений на основе ченностно-ориентированного подхода 


\section{Заключение}

Перспективы угольной отрасли Монголии во многом связаны с развитием экономики и потребностей в угле в Китае. При этом важным моментом является осуществление правильной ценовой политики, когда рост ценности угольных месторождений Монголии и повышение спроса на продукцию угольной отрасли будет меняться в соответствии с расширением поставок продукции производителей угля на рынок Китая. Другим определяющим для развития угольной отрасли Монголии моментом является обеспечение снижения затрат посредством государственного регулирования тарифов на грузоперевозки и строительства железных дорог для преодоления логистических трудностей.

Таким образом, эффективность использования конкурентных преимуществ Монголии в области использования месторождений угля потребует комплекс мер технологического менеджмента рационального природопользования как со стороны государства, так и самих компаний - производителей. В частности методика ранжирования участков угольных месторождений по признаку величины приращённой ценности экспортируемого угля может быть использована для обоснованного комплекса мер по технологическому менеджменту рационального природопользования.

\section{Литература}

1. Чимэддорж Удвалноров Проблемы добычи и использования угля в Монголии // Экономические проблемы и механизмы развития минерально-сырьевого комплекса (Российский и мировой опыт) Международная научная конференция, 2-3 декабря 2015 г. Сборник научных трудов. С. 107-109.

2. Статистика минеральных ресурсов и нефти [Электронный ресурс] / Улан-Батор. - 2017. - 37 с. Официальный сайт Управление минеральными и нефтяными ресурсами. URL: https:/www.mrpam.gov.mn/

3. Очирбат Пунсалмаагийн Угольная промышленность Монголии: состояние и перспективы развития // Записки Горного института. 2017. Т. 226. С. 420-427.

4. Василенок В.Л., Шапиро Н.А. Стратегии и инструменты управления экономикой: отраслевой и региональный аспект// Финансы и кредит. 2006. № 23 (227). С. 80-83.

5. Плачков С.Г. Энергетика от огня и воды к электричеству. Официальный сайт Энергетика: история, настоящее и будущее. URL: http://energetika.in.ua/ru/books/book-1/part-2/section-7/7-6 (2013).

6. Хайкин М.М., Кныш В.А., Подолянеи Л.А. Индустриально-сырьевая экономика: проблемы регулирования и управления. ООО «Издательство «ЛЕМА».: С-Пб, 2017. 109 с.

7. Экономический рост [Электронный ресурс] Официальный сайт Статистическая информационная служба Монголии. URL: http://www.1212.mn/ (2017г)

8. Coal market study : Report ERI / Khashchuluun Ch. - Ulaanbaatar : Economic Research Institute, 03.2017. - 68 pp.

9. Чимэддорж Удвалноров Развитие транспортной инфраструктуры как фактор повышение эффективности минерально-сырьевого сектора // Современные аспекты экономики. № 11(231). 2016. С. 25-29.

10. Баланс угля 1989-2017 г. - [Электронный ресурс] Официальный сайт Статистическая информационная служба Монголии. URL: http://www.1212.mn/ (19.07.2017).

11. Транспортные расходы [Электронный ресурс]: Официальный сайт АО «Улан-Баторская железная дорога» (АО «УБЖД»). URL: http://achaa.ubtz.mn/.

12. Об утверждении стандарта тариф на транспортировку [Электронный ресурс]: Официальный сайт Министерство дорог и развития транспорта Монголии. URL: http://mrtd.gov.mn/.

13. Таразанов И. Итоги работы угольной промышленности России за январь-декабрь 2016 года // Уголь. - 2017. № 3. С. 36-51.

14. Плакиткина Л.С., Плакиткин Ю.А. Потребление угля в основных регионах и странах мира в период 20002015 гг. Анализ, тенденции и перспективы // Уголь. 2017. №1. с. 57-62.

15. Баярсайхан, Б. Нүүрсний давхаргын метан хийн судалгаa / Б. Баярсайхан, Б. Авид // Шинжлэх Ухааны Академийн мэдээ. 2010. №03(197). С. 33-42.

16. Daily Market Watch [Электронный ресурс]: Официальный сайт Fenwei Energy Information Services Co., Ltd. URL: http://en.sxcoal.com/ (14.03.2017).

\section{References}

1. Chimehddorzh Udvalnorov Problemy dobychi i ispol'zovaniya uglya v Mongolii // Ehkonomicheskie problemy i mekhanizmy razvitiya mineral'no-syr'evogo kompleksa (Rossijskij i mirovoj opyt) Mezhdunarodnaya nauchnaya konferenciya, 2-3 dekabrya 2015 g. Sbornik nauchnyh trudov, P. 107-109. 
2. Statistika mineral'nyh resursov i nefti [EHlektronnyj resurs] / Ulan-Bator. 2017. 37 p. - Oficial'nyj sajt Upravlenie mineral'nymi i neftyanymi resursami. URL: https://www.mrpam.gov.mn/

3. Ochirbat Punsalmaagiin. Coal Industry in Mongolia: Status and Prospects of Development // Zapiski Gornogo instituta. 2017. Vol. 226. P. 420-427. DOI: 10.25515/PMI.2017.4.420.

4. Vasilenok V.L., SHapiro N.A. Ctrategii i instrumenty upravleniya ehkonomikoj: otraslevoj i regional'nyj aspekt // Finansy i kredit. 2006. № 23 (227). P. 80-83.

5. Plachkov S.G., EHnergetika ot ognya i vody k ehlektrichestvu. Oficial'nyj sajt EHnergetika: istoriya, nastoyashchee i budushchee. URL: http://energetika.in.ua/ru/books/book-1/part-2/section-7/7-6 (2013).

6. Hajkin M.M., Knysh V.A., Podolyanec L.A. Industrial'no-syr'evaya ehkonomika: problemy regulirovaniya i upravleniya. Izd-vo: OOO "Izdatel'stvo "LEMA" . Sankt-Peterburg, 2017. 109c.

7. Ehkonomicheskij rost [EHlektronnyj resurs] Oficial'nyj sajt Statisticheskaya informacionnaya sluzhba Mongolii. URL: http://www.1212.mn/ (2017g).

8. Soal market study : Report ERI / Khashchuluun Ch. - Ulaanbaatar : Economic Research Institute, 03.2017. - 68 pp.

9. Chimehddorzh Udvalnorov Razvitie transportnoj infrastruktury kak faktor povyshenie ehffektivnosti mineral'nosyr'evogo sektora // Sovremennye aspekty ehkonomiki, №11(231), 2016. - C. 25-29. Economic growth [Electronic resource] Official website Statistical information service of Mongolia. URL: http://www.1212.mn/ (2017)

10. Balans uglya 1989-2017 g. - [Ehlektronnyj resurs] Oficial'nyj sajt Statisticheskaya informacionnaya sluzhba Mongolii. URL: http://www.1212.mn/ (19.07.2017).

11. Transportnye raskhody [EHlektronnyj resurs]: Oficial'nyj sajt AO «Ulan-Batorskaya zheleznaya doroga» (AO «UBZHD»). URL: http://achaa.ubtz.mn/

12. Ob utverzhdenii standarta tarif na transportirovku [EHlektronnyj resurs]: Oficial'nyj sajt Ministerstvo dorog i razvitiya transporta Mongolii. URL: http://mrtd.gov.mn/

13. Tarazanov I. Itogi raboty ugol'noj promyshlennosti Rossii za yanvar'-dekabr' 2016 goda // Ugol'. 2017. №3. P. 36-51.

14. Plakitkina L.S., Plakitkin YU.A. Potreblenie uglya v osnovnyh regionah i stranah mira v period 2000-2015 gg. analiz, tendencii i perspektivy // Ugol'. 2017. №1. P. 57-62.

15. Bayarsajhan, B. NYYrsnij davhargyn metan hijn sudalgaa / B. Bayarsajhan, B. Avid // SHinzhlehkh Uhaany Akademijn mehdeheh. 2010. № 03(197). P. 33-42.

16. Daily Market Watch [EHlektronnyj resurs]: Oficial'nyj sajt Fenwei Energy Information Services Co., Ltd. URL: http://en.sxcoal.com/ (14.03.2017).

17.

Статья поступила в редакцию 19.01.2018 2. 